\title{
Social Stratification and Its Perception in Austria and Central-East Europe from 1960 to 2015: Historical Legacies, Socialist Pasts and Recent Developments
}

\author{
MAX HALLER and MARKUS HADLER* \\ University of Graz
}

\begin{abstract}
This article compares Austria with three of its former state-socialist neighbouring countries: the Czech Republic, Slovakia, and Hungary. The authors are guided by the assumption that it is necessary to analyse changes in both the structure and the perception of inequality and that the two are interconnected. They assume that some general differences exist as a result of the legacy of state socialism in the three post-communist countries, but also that significant differences exist between those three countries themselves that stem from their different paths of development in the 19th and early 20th centuries. In the first part of this article, differences in the societal-political aims of a Western country such as Austria and those of state-socialist countries are discussed. The authors argue that the state-socialist countries were able to contain income inequality but were less successful at limiting other aspects of inequality. Austria, on the other hand, was able to avoid the severe income inequalities of the capitalist system by introducing democratic-corporatist institutions and a strong welfare state. In the second part of the article the authors investigate the subjective perception of inequality based on the ISSP inequality surveys. The majority of the population in all four countries think that income differences are too large, but there are significant differences in how people perceive and evaluate the stratification structure: in Austria, individuals rank themselves significantly higher than do people in the other three countries and see their society as dominated by the middle classes. The opposite is true in Hungary, where most people think that they live in a society characterised by a small elite, and they see the mass of the people at the bottom.
\end{abstract}

Keywords: social stratification, inequality, Austria, state socialism, perception of inequality

Sociologický časopis/Czech Sociological Review, 2019, Vol. 55, No. 6: 697-733

https://doi.org/10.13060/00380288.2020.55.6.490

\footnotetext{
* Direct all correspondence to: Max Haller, Institute of Sociology, University of Graz, e-mail: max.haller@uni-graz.at; Markus Hadler, Department of Sociology, University of Graz, e-mail: markus.hadler@uni.graz.at.
} 


\section{Introduction}

Differences between the four neighbouring countries of Austria, the Czech Republic, Hungary, and the Slovak Republic in terms of stratification and inequality are frequently explained by the experience of state socialism in the latter. This view is not surprising considering the post-war developments in the CentralEast European Countries (CEEC). Since 1945 Austria has been through a dynamic and continuous process of development that vaulted it from a position below the West European average to one of the five richest countries in the European Union; during this period, its eastern ${ }^{1}$ neighbouring countries were lagging behind or even falling back significantly [Therborn 1995]. The transition to a capitalist economic and democratic system in the three latter countries in the early 1990s and their accession to the EU in 2004 ushered these countries also onto a path of strong economic growth. Many observers thus assumed that the differences between the four countries would soon diminish. Yet, it is evident that such a view is too simplistic because it ignores many historical developments and legacies, as we will show in this article.

Our overarching sociological perspective is that both objective social structures and subjective perceptions of inequality need to be analysed. It has to be appreciated that recently many economists [e.g. Milanovic 2005; Stiglitz 2013; Piketty 2014] have analysed the structural trends in inequality and pointed to the disruptive effects of increasing inequality. However, objective structures of inequality can be perceived and evaluated by a population quite differently, depending on the dynamics of economic growth, the societal and political ideologies prevailing in a society, and the position of a person in the social structure. These factors constitute the dominant view or consciousness about the class structure [Ossowski 1963]. In line with this basic assumption, we first offer an overview of the historical and current political, social, and economic developments in these four countries and subsequently an analysis of the subjective perceptions of inequality and social structures.

The discussion of objective structures and subjective perceptions is guided by three general hypotheses: First, we assume that a main difference between the four countries will derive from the socialist past of three of them. The embedding of Austria in the Western political-economic system, with its higher level of competitiveness and innovation, its strong collective representations of capital and labour, and its democratic, consensually oriented political institutions, has led to more dynamic and consistent socio-economic transformations and more sustainable improvements in the life conditions of the population. In the former statesocialist countries, the full mobilisation of human resources, including women, led to rapid industrialisation. But, central planning and an increasing shortage of

\footnotetext{
1 'Eastern Europe' refers to the former socialist regimes. In a geographical sense, Prague is further west than Vienna.
} 
consumer goods may have led to stress and a reduced quality of life for many social groups. The collectivisation of agriculture, the abolishment of private property, and the focus on heavy industry resulted in faster growth of the working class in Czechoslovakia and Hungary than in Austria, where the petty bourgeoisie and employees in services were the segments of the population that were increasing in size. Because of the strong position of working-class organisations in Austria (unions and the Social Democratic Party), the increase in inequality has remained rather low. The resulting differences between Austria and its three neighbouring countries in Central-Eastern Europe have not been equalised in the two and a half decades since their transition from a socialist to a capitalist system given the tenacity of social structures and processes.

Second, we consider differences and similarities among the former statesocialist countries, which are often seen as a more or less homogeneous group. The internal differences and the differences to Austria derive from the countries' specific historical heritages and developments. A comparison of these three countries showed that specific national factors, alongside the differences between the two political systems, were significant in explaining differences in patterns of social mobility [Haller, Kolosi and Robert 1990]. Hungary has a stronger heritage of inequality than the Czech Republic; therefore, we assume that objective levels of inequality (there) were higher until the mid-20th century, and four decades of the communist regime were unable to level these differences. For this reason, we expect that Hungary is still more unequal than the Czech Republic. Slovakia, which was a part of Hungary for centuries, might be in this regard figure somewhere between the Czech Republic and Hungary. Further, while all three countries became members of the EU in 2000, the Czech Republic was the least enthusiastic, and, like Hungary, it is still not a member of the Euro group. The Slovak Republic and Hungary were much more open to international connections, and this was especially true in Slovakia, where investments from Western firms contributed massively to its economic growth. In sum, we hypothesise that these developments shaped the influence of state socialism after 1989 and resulted in differences both in the social structures and perceptions across our four countries.

Third, we propose that these specific historical backgrounds also shape current subjective views on inequality. Comparing the standard of living in CentralEast European countries to that in neighbouring Western European countries (Austria and Germany in particular) is highly informative for understanding subjective perceptions of the social structure and for evaluating social inequality. These comparisons are fostered by the intense processes of labour mobility between these countries and Austria in recent times [Haller and Verwiebe 2016]. We expect, therefore, that the subjective images of class structure and social inequalitywill differ more between the four countries than the objective levels of inequality do; people in the former state-socialist countries will probably have a more critical view of the social structure and inequality. 
In the next section, we discuss some of the main differences in the goals and strategies of state-socialist societies concerning social equality compared to Austria's system of a 'social partnership'. This part is followed by a discussion of the socio-economic development and social-structural changes in the four countries since World War II. In the fourth section, we present findings on changes in the perceptions of inequality based on ISSP-surveys on inequality carried out in 1987, 1992, 1999, and 2009. The conclusion ties together our findings and discussions on objective structures and subjective perceptions.

\section{Two roads: state socialism vs corporatist 'social partnership'}

State socialism in East Europe is highly relevant from a sociological and a political perspective, as it can be considered to have represented a big experiment in redistribution and 'destratification' [Lenski 1978; Szelenyi 1998; Večerník 2009: 122]. The central aims and political measures of state socialism (following the Soviet model) can be summarised in five points: (1) the nationalisation of industrial enterprises and the creation of regular five-year-plans to regulate the allocation of funds and resources and establish goals for industrial production and services; (2) a focus on the development of heavy industry at the expense of consumer goods and services; (3) an effort to utilise all the labour resources in society, in particular the full inclusion of women in gainful work; (4) the expansion of the education system; (5) the extensive provision of social services, particularly for families with children, and the provision of cheap housing. All these aims were justified by the overall goal to generate basic equality among all citizens.

Western social scientists who analysed the changes in state-socialist countries were impressed by their success in achieving rapid industrialisation and deep-reaching social-structural changes [Lane 1971; Parkin 1972; Connor 1979]. But the emergence of a new divide between the Nomenclature elites and the rest of the population was viewed with scepticism - including by political writers inside the system [e.g. Djilas 1959; Voslensky 1984]. Very few observers, however, foresaw the breakdown of the whole system within a generation. Western analysts seem to have been misled to some degree by descriptions of the system provided by the state-socialist elites themselves [von Beyme 1994: 17], although few would have agreed with the rosy picture of the future of state socialism put forth by Hegedüs [1977]. After 1989/1990, influential Western analysts argued that the main factors responsible for the collapse of communism were the deficiencies associated with central planning. Liberal economists and international institutions (IMF, World Bank), therefore, urged a radical and fast transition to capitalist principles in order to avoid counterproductive effects and counter the stubborn resistance of the old elites. It was expected that with the introduction of a market economy post-communist countries would quickly catch up with neighbouring countries such as Austria to the West. 


\section{State socialism and equality}

It is widely assumed that social equality was the central aim of socialist societies. A multivariate analysis of the determinants of income inequality in 139 countries has shown that the experience of state socialism did in fact reduce the level of inequality significantly [Haller and Eder 2015: 106-111; see also Večerník 2009: 73ff]. However, the relevance of equality as a political goal declined over time [Haller and Mach 1984; Nee 1989; Szelenyi 1998; Ivanova 2007]. Also, socialist politics had to reconcile the values of equality and achievement. Therefore, the idea of equality in opportunities and the goal of increasing the educational level of the children of 'workers' was a central political focus [Connor 1979]. Correspondingly, the expansion of the education system was considered to be very important, and this included establishing an extended secondary education system in order to enable the ascended members of the cadres to make up for the gaps in their higher education. However, research has shown, particularly in Hungary, that the significant increase in educational opportunities for children from farm and working-class backgrounds was primarily the result of structural changes (the extension of the school system) and was less due to policy measures (like quota systems) [Szelenyi 1998; for the GDR see Geissler 1983; Solga 1995]. The aim of establishing equality was certainly realised with respect to inequalities in officially recognised and published working incomes. The range from the lowest to the highest income was much smaller than in Western countries [Večerník 2009: 83]. Moderate income differences also existed in relation to education and between blue- and white-collar workers. However, by the 1960s and 1970s, critical voices were already being raised by economists and sociologists (Ota Sik, Pavel Machonin) concerning the negative effects that levelling down (Gleichmacherei) has on achievement motivation, economic innovation, and growth [see Connor 1979]. Internal critics [Djilas 1959] and Western social scientists [von Beyme 1975; Konrad and Szelenyi 1979] pointed to the fact that the main aim of state-socialist systems was the preservation of power and stability in the political sphere and industrialisation and modernisation in the economic sphere. To achieve this aim, all of society's resources-including the labour power of women-had to be mobilised.

The socialist equalisation process was also less successful in terms of overall life chances: non-workers and in particular cadres of all sorts enjoyed many additional privileges which made their situation much better than that of rank-andfile workers. People in the lower classes, women, and families were left exhausted by long working hours, long waiting times to get scarce goods and services, and constricted living conditions (small apartments). 


\section{Consensual politics and the 'social partnership' in Austria}

'Capitalist' Austria was also able to keep economic inequality at a rather moderate level. This was due to the implementation of consensual democratic policies and a strong welfare state-like in the other two German-speaking countries Germany and Switzerland [Haller, Eder and Müller 2015]. Throughout the four postwar decades the bourgeois Christian-Democratic People's Party (Österreichische Volkspartei) and the Social Democratic Party were the decisive political forces. This was connected to the existence of strong collective organisations of workers (unions and chamber of workers) embedded in an effective social partnership (Sozialpartnerschaft) with the representatives of business and capital (chamber of commerce and federation of Austrian industries). This arrangement has been called 'corporatist tripartism'; it prevailed in similar forms also in other Continental European countries and in Scandinavia [Lehmbruch 1982]. In Austria, this economic-political system ensured low levels of industrial conflict, steady economic growth, and a continuous rise in income paralleling the increase in productivity [Pelinka 1981; Prisching 1996]. Also, all governments (culminating in the period 1970-1983 when social-democratic chancellor Kreisky won the absolute majority of votes in the elections of 1971, 1975, and 1979) promoted the substantial expansion of the education system and the welfare state. These developments contributed to an improvement of human capital and an increase of upward social mobility [Haller 1982; Altzinger et al. 2013; Leitner and Wroblewski 2019]. In comparative terms, educational and mobility opportunities in Austria were clearly above the OECD average [OECD 2010]. Austria was also able to prevent a significant increase in income inequalities, which in many Western countries had begun to occur since the onset of neoliberalism in the mid-1980s. In the 1980s, German newspapers were already expressing admiration for the Austrians' economic success, which had even surpassed the German Wirtschaftswunder. Austrian national identity and pride increased strongly as a consequence [Haller 1996].

However, it would be too simplistic to ascribe this success mainly to a farsighted policy or to the particular abilities and industriousness of the Austrians. An economic historian has rightly remarked that policy decisions in Austria were often reactions to socio-economic changes rather than their causes [Mathis 2007]. A good example is the privatisation of state industry in Upper Austria and Styria (then called VOEST), which went nearly bankrupt in the late 1980s as a result of ineffective management and political interventions (for instance, to prevent worker lay-offs). After privatisation, this industrial conglomerate became a highly competitive and successful enterprise (Voest Alpine). The success of Austria was also supported by a number of lucky circumstances, such as its central location between the thriving South German and North Italian regions; its possession of a diversified landscape and a rich array of historical monuments ensuring both summer and winter tourism; and its inheritance of prosperous towns and cities from the late Middle Ages. ${ }^{2}$ 


\section{Social-structural developments: 1960-2015}

The above description of state socialism must be supplemented in two ways: First, we need to depart from considering East-European state-socialist countries as a single block, without acknowledging the differences between them [see also von Beyme 1975: 18; Haller 1990]. Second, we need to overcome the neglect of the historical differences and similarities that existed during the modernisation process that were connected with the effects of the Habsburg Monarchy. ${ }^{3}$ We will thus outline the deep-reaching social-structural differences that existed between Austria, the Bohemian lands (today the Czech Republic), and Hungary under the Austro-Hungarian Monarchy and, subsequently, present some basic data on socio-economic development and income inequality since 1960.

\section{A differing social-structural and political heritage}

At the onset of the industrial modernisation in the 19th and early 20th centuries, the four countries were part of the Habsburg monarchy. The American historian David F. Good [1984] has disproved the formerly widespread thesis that the Habsburg Empire was not able to catch up with the industrialisation and modernisation happening in West Europe in this period. However, there existed significant differences between the more developed western and the less developed eastern parts of the monarchy. Lower Austria and the Czech lands (Bohemia) ${ }^{4}$ were comparable to the most prosperous regions in Western Europe, while Hungary lagged behind. Inequality was much greater in Hungary (which at this time included present-day Slovakia) than in the Austrian-Czech lands. In fact, Hungary has been characterised as 'the quintessential home of a landed aristocracy' before World War I [Eddie 1989: 249; Kopsidis 2006]. It was characterised by a high level of inequality in agriculture, where the landlord nobility owned the largest swathes of arable land, while the peasant masses were poor farmers with small plots or were landless labourers. This structure emerged in the course of the 19th century, while Hungary became the 'breadbasket' of Austria-Hungary, fostered by the political protection of estate owners and their large farms. Indus-

\footnotetext{
${ }^{2}$ Even more than 250 year ago, Austria was described in the encyclopaedia as an affluent country where people live much better than in its East European neighbour countries [Zedler's Lexikon, edited in 1741.]

${ }_{3}$ The economist Leon Podkaminer (Vienna Institute for International Economic Studies), for example, does not differentiate between the Central European (e.g., Poland, the Czech Republic, and Slovakia, Hungary) and East European countries (the countries of the former USSR). He refers only to CEE countries in this otherwise very informative study on this geographical area.

${ }^{4}$ Lower Austria is the province surrounding Vienna; the present-day Czech lands were formerly called Bohemia; this was the name of an independent kingdom in the mediaeval and early modern age.
} 
trialisation only made headway in the food-processing (mainly milling) sector and was financed in large part by an influx of capital from Austria. Thus, a dualism emerged in the agricultural market between the extensive production of the large estates and unproductive small agriculture. The abolition of serfdom in Hungary in 1848 was not designed to support industrial development but rather to provide cheap labour for the big estates [Kopsidis 2006]. Members of the nobility (many of whom were pauperised) were contemptuous of manual work, while the rural surplus population could not find jobs in industry and sank into poverty. These social-structural differences were closely tied to differences in the education systems. While Austria and Bohemia both had a well-developed system of education in place by the late 19th century, in Hungary no free education was provided even at the elementary level [Connor 1979: 29ff.; Kaser and Radice 1985: 119, 160; Szelenyi 1998: 6ff.].

Significant changes with long-lasting effects took place when the Habsburg Empire disintegrated at the end of World War I. In the 1920s, the old and deeprunning ties between Austria, the new Republic of Czechoslovakia, and Hungary were curtailed, and this caused economic hardships in all three countries and contributed to the deep economic crises of the 1920s and early 1930s. In Hungary the conservative government attempted to address the urgent need for land reform after World War I, but with moderate results: 400000 families were given plots, but they were so small that the families could barely live off them. At the same time, a great deal of land was given to former members of the national army, who were supporters of the authoritarian Horthy regime. Around 1930, $54 \%$ of Hungarians were still working in agriculture (most of them in rather poor conditions), compared to 30\% in Czechoslovakia and 27\% in Austria [Möller 1974: 210]. Significant improvements were, however, achieved in the Hungarian education and health systems in the interwar period [Connor 1979: 245].

The idea of societal equality was much more entrenched in the Czech lands than it was in Hungary. Its origins there can be traced back to the Hussite revolution in the 15th century, which had both national and social aims; one consequence of this was a strong focus on education. Another factor can be seen in the fact that Bohemia and Moravia fell under Habsburg rule and consequently the high-ranking aristocracy in these lands was made up of Austrians. Domination by non-Czechs may have led to Czechs placing a high value on equality as (a form of) in-group cohesion among the dominated. After World War II, the communists' take-over of political power had a relatively strong base in Czechoslovakia (the Communist Party received 38\% in 1946).

Far-reaching land reforms and redistributions were undertaken in communist East-Central Europe after World War II. In Czechoslovakia, the lands of nearly 3 million expelled Germans were confiscated by the state, which give land reform a distinctively national flavour [Kaser and Radice 1985: 585]. In Hungary, the traditional landholding gentry was practically abolished. Land was first redistributed to farmers who supported this reform. But later the collectivisation of agricul- 
ture and the creation of large, but not very productive kolkhozes took place in both countries, which often involved harsh intimidation and violence [Djilas 1959]. In addition, investments in agriculture were neglected in favour of industry, resulting in shortages of agricultural products and a massive exodus of the population from rural areas. Later, in the 1960s, reforms in Hungary reduced central planning and public debt and partially introduced market prices; in the aftermath of these reforms agricultural production rose significantly [Kopsidis 2006].

From 1946 on, Czechoslovakia and Hungary were incorporated into the Soviet-dominated economic area. The common trade and economic area, COMECON, was established by the Soviet Union out of political and military considerations in order to control their new satellite states in the communist bloc and to profit from their industrial capacities [Haller 2011]. ${ }^{5}$ This new foreign economic relationship made CEE countries (in particular Czechoslovakia) focus strongly on heavy industry and machinery (including arms production). It also had the effect of curtailing technological progress as the countries were cut off from competition with industrial and technological developments in the West. From 1989 onwards there again occurred a radical reorientation of the relations of the postcommunist CEE countries to the West and the European Union [Nee 1989]. As a consequence there was a strong influx of Western capital and the take-over of large segments of the economy of all CEE countries [Haller 2008: 140-151]. This also led to a strong dependence on foreign domestic investment from Western countries [Podkaminer 2013: 30; Haller 2008: 140-149]. However, in terms of the recruitment of business leaders and company management, the transition did not involve a total break with the past: many members of the former nomenklatura cadres were able to maintain their position, because they possessed relevant social capital (they belonged to the right power networks and had access to insider information) and often used somewhat aggressive, semi-legal or illegal methods to build up large businesses. Their previous positions and contacts and their knowledge of specific organisations were more decisive factors for their success in the privatisation process than human capital [Mejstrik 1997]. Some researchers speak about a 'revolution of deputies', wherein there was a systematic exchange of positions between former company directors and their assistants, with the latter taking over the reins of management [Večerník and Matěju 1999: 84-85]. The problem for the transition process from state socialism to a market society and democracy was that an economic and political transformation both had to be achieved at the same time [Offe 1994; Baravalle 2009]. Yet, a positive significant change was that returns to education increased significantly [Matěju and Lim 1995; Lengyel 2007].

\footnotetext{
5 The first uprisings in East Europe - in East Berlin in 1951, and in Budapest in 1956were to a large degree directed against this forced integration into a new, less developed economic area.
} 
Sociologický časopis/Czech Sociological Review, 2019, Vol. 55, No. 6

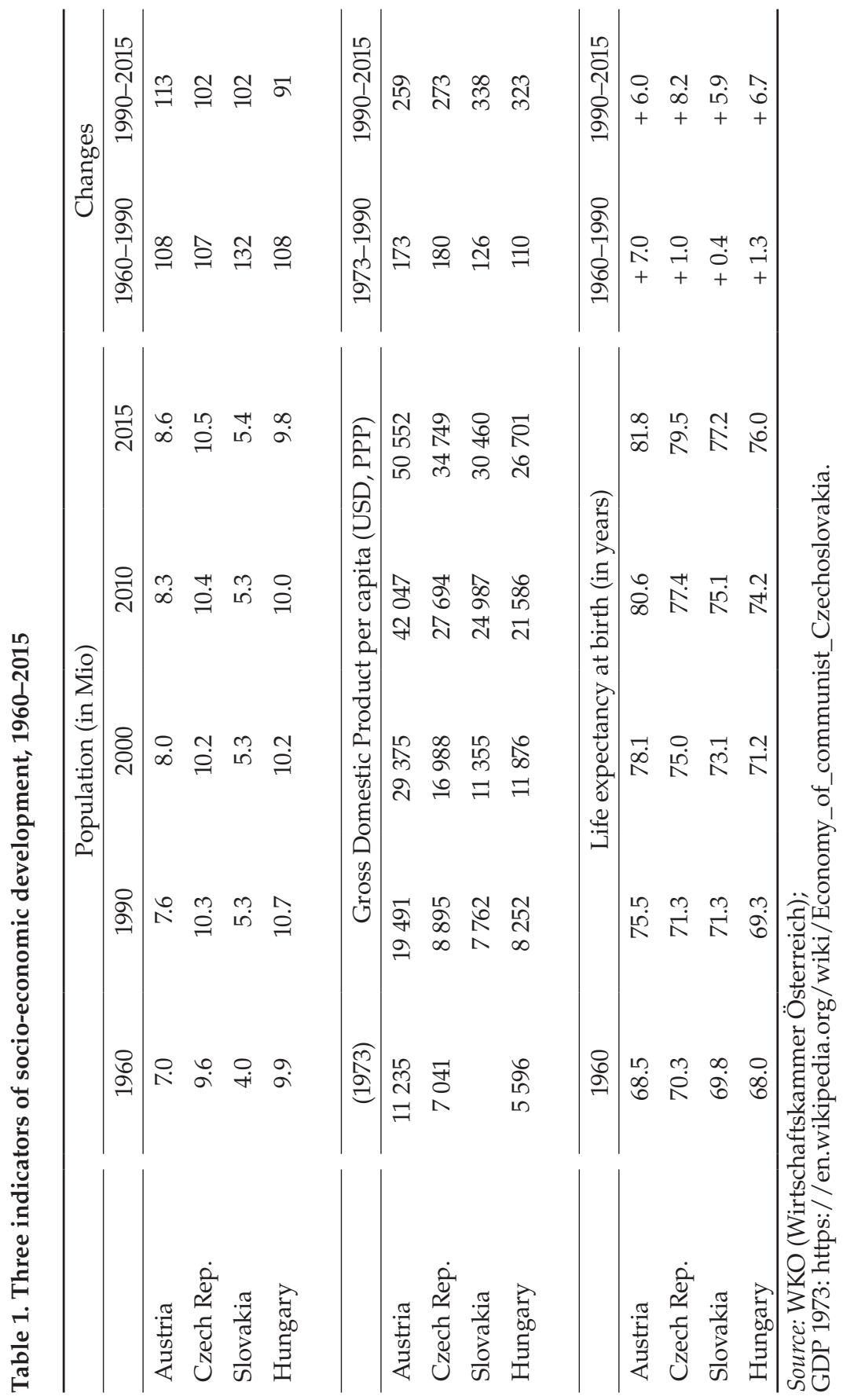




\section{Trends in socio-economic development and social inequality}

We now present some basic empirical data and consider economic and social development in Central Europe since World War II, distinguishing the state-socialist period (ca. 1950-1990) and the period from 1990 to 2015. ${ }^{6}$ Table 1 provides an overview of the changes in three basic socio-economic indicators in the four countries compared: GDP per capita, size of population, and life expectancy. Subsequently, Figure 1 shows the development of income inequality over time, measured by the GINI index.

The basic economic indicator of Gross Domestic Product (GDP) per capita shows a significant increase in all periods and in all four countries. In the statesocialist period, 1960-1990, it increased quite strongly in Austria and Czechoslovakia and somewhat less in Hungary. Between 1990 and 2015, the increase was even much stronger: GDP per capita increased by more than two-and-a-half times in Austria and the Czech Republic and by more than threefold in Slovakia and Hungary. Thus, the distance between Austria and its neighbouring countries decreased significantly, although the differences were still considerable.

A good indicator of the general living conditions in a country is life expectancy at birth. In this regard we can see a large difference between the periods before and after the transition in 1989/1990 in the former socialist countries. Between 1960 and 1990, life expectancy increased significantly in Austria: from 68.5 to 75.5 years-an addition of seven years. Compared to this substantial improvement, in all three state-socialist societies the increase was rather modest: only between 1 and 1.5 years. Since the transition in 1990, however, life expectancy has also been increasing in the three post-socialist countries.

How can we explain this surprising fact? There can be only two reasons for the factually modest improvement in this regard: either, the quality of social benefits and services was not as good as in Austria, or other processes may have thwarted their success. ${ }^{7}$ General support for the first conjecture is provided by Jiří Večerník, who writes that the communist state bestowed irregular 'gifts' on citizens, couching them in paternalistic rhetoric: 'But in fact social protection was the lowest priority in state spending, well below spending on the army and police, industry and agriculture, and the party and state bureaucracy.' [Večerník 2009: 145]. To make up for the low pensions paid by the state, the state kindly allowed

\footnotetext{
${ }^{6}$ Our data focus on the period from 1960 onwards due to limitations in data availability. Further, as a reviewer pointed out, it is important to keep in mind that policies differed significantly in the first years after World War II, when half of Austria was occupied by Russia and Stalin was in power.

7 Altogether, social expenditures in Austria were about 30\% of GDP, in its three neighbouring countries 18-19; absolute in expenses per head were about 12000 euro in Austria, 3000 in the Czech Republic, 2600 in Slovakia and 2100 in Hungary. See WKO (Wirtschaftskammer Österreich), Sozialausgaben (http://wko.at/statistik/eu/europasozialausgaben.pdf) (retrieved 23 November 2018).
} 
pensioners to couple pension benefits and wages; however, the number of days spent in employment were unlimited only for manual workers, while they were limited to 120 working days per year for non-manual workers. As a consequence, however, time-stress increased [Haller and Mach 1984]. In this respect an international comparison showed that time spent on work and household chores was higher in Czechoslovakia than in France and much higher than in the USA, and free time was correspondingly shorter [Lupri 1983: 27]. A more recent analysis of the experience of leisure time using data from the ISSP 2007 also revealed that people in all post-communist East European societies typically felt higher levels of stress in their leisure time [Haller, Hadler and Kaup 2013]. Austria was in the group of countries with the lowest level of leisure-time stress: only $14 \%$ of the respondents share this experience often. In the Czech Republic, 30\% of respondents had this experience, and in Hungary $44 \%$.

Table 1 presents another indicator of the situation of people in the four countries compared here and that is population development. We can say that an increase in the population in general is indicative of positive development perspectives of a country, either because young people are optimistic about their life prospects and ready to establish a family or because the country is attracting immigrants from other countries [Haller and Ressler 2005]. The data show that in the three decades before 1990 the population increased slightly in three countries (AT, CZ, and HU) and was to some extent stronger in Slovakia. Since the transition, trends have changed significantly: while Austria experienced a continuous population increase, the Czech and Slovak populations stagnated and the Hungarian population even decreased (in absolute terms, by nearly half a million people). One reason for these differences was migration: Austria had experienced considerable immigration over many periods since 1960, but the state-socialist countries-except the Czech Republic - experienced emigration. The number of foreign-born people in Austria in 2015 was 17\%, while in the three other countries it was only $3 \%$ to $5 \%,{ }^{8}$ a total of $21 \%$ of Austrians have a migrant background. Today these four countries, in fact, constitute a new migration space [Haller and Verwiebe 2016], one that is, however, somewhat asymmetrical. It comprises a considerable amount of circular mobility and commuting in the shared border regions of western Slovakia and Hungary and the Vienna metropolitan area in eastern Austria. The main reason for this migration is certainly the significant pay gap between Austria and its Central European neighbours. ${ }^{9}$ It has also been shown for all post-communist East European countries, that the proportion of people working in West Europe is directly correlated with these relative pay gaps: the bigger the gap, the more people there are working in West Europe [Bahna 2016]. While

8 United Nations Population Division, Republic of Economic Affairs (available at https:// de.wikipedia.org/wiki/Einwandereranteile_nach_Ländern (retrieved 23 November 2018). 9 Between Austria and Hungary, it is 3:1 among the highest, and 4:1 among the lowest income groups [Eurostat data 2016]. 
Figure 1. Income inequality over time

GINI of disposable household income post tax

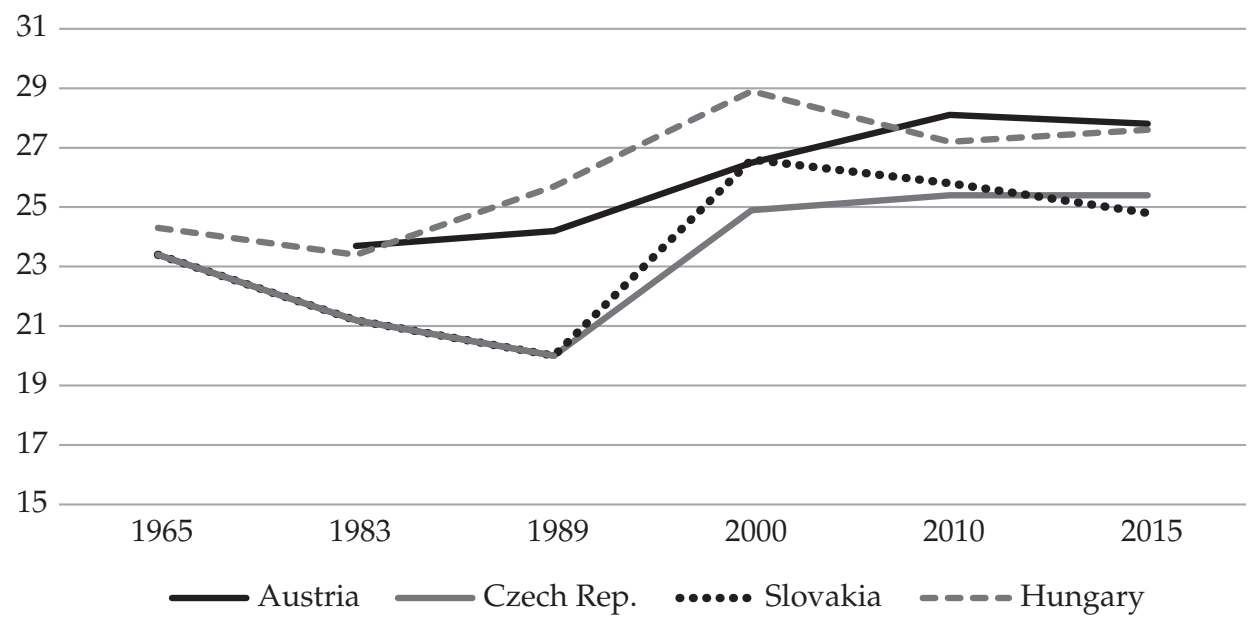

Source: Solt [2016]; first data point: Austria: 1983, CSFR 1965, and Hungary 1962.

the immigration of mostly well-educated working-age people provided an economic stimulus for Austria, emigration in some respects had a negative impact on the economies of post-communist East Europe, leading to a shortage of skilled workers [Atoyan et al. 2016]. ${ }^{10}$

As for changes in economic inequality, Figure 1 shows the levels and changes in economic inequality during the era of state socialism (1960-1990) and since then. The data on income inequality in state-socialist countries in general have to be viewed with caution; they are probably an underestimation of the degree of inequality in those societies given that poverty, for instance, was a taboo subject [Večerník 2009: 160; Lengyel and Rsotovány 2011: 126ff.].

There are three noteworthy findings alongside the most conspicuous fact that income differences and changes in income are rather modest. First, in Austria we can observe a continuous but only slight increase in recent decades. This is far below of what is observed in other Western countries. Second, in all three postsocialist countries inequality is increasing in the first decade after the transition (1990-2000) but remains rather stable afterwards. Finally, Hungary experienced a change that was different from the former Czechoslovakia in that inequality

10 This is less true for the Czech Republic and Slovakia, but is most serious for more eastern countries like Romania and Bulgaria. 
seems to have increased somewhat during the period of state socialism. Today, the absolute size of the reported Gini coefficients is very similar and is between 25 and 28 in all four countries. According to recent data from the Luxembourg Income Study, Austria and Hungary went from being among the 'most equal countries' (with a Gini below 25) in the early 1980s to being in the group of 'somewhat equal countries' (Gini 25-30) in the late 2000s; the Czech Republic and Slovakia remained in the 'most equal group' during this time [Nolan et al. 2014; Toth 2014, 2016]. This relative stability of income inequality in all three post-communist CEEcountries contrasts sharply with the massive changes in Russia and China during and after the transition. There, inequality was also rather low under state socialism but ballooned after the down-break of the system in the Soviet Union and the introduction of strong market mechanisms in China [Haller and Eder 2015: 195]. ${ }^{11}$

Summarising the findings of this section, we might conclude that they present a puzzle. After forty years of state socialism in the three East-Central European societies, which in fact retarded their development, the transition to market societies and parliamentary democracies has brought them onto a dynamic path of growth. This is true not only in economic terms, but also in terms of the quality of life. But why are so many people leaving their countries for work in the West (though this is not so much the case for the Czech Republic)? Differences in income alone cannot explain it. With the exception of Slovakia, unemployment rates are rather low in these countries and moderate also among young people. ${ }^{12}$ We think that some of the social structural trends and perceptions of inequality provide further insight into these questions.

\section{The development of social and class structures since 1990}

Concluding this section, we provide a brief overview of structural changes since the transition in the early 1990s focusing on changes in the levels of education, labour force participation, and occupational class structure. For this purpose, we use findings from the ISSP surveys on inequality carried out between 1987 and 2009 and data from the OECD and the ILO.

The ISSP data on education clearly reflect old structural differences between the three (and today four) countries, which were outlined in the previous section. In the early 1990s, one-third of Austrians and Hungarians had only basic education [see also the Ministry of Education 2008: 44]; the corresponding figures were between $15 \%$ and $20 \%$ for the Czech Republic and Slovakia. Corroborating OECD data (available only from the mid-2000s onwards) also show that the rate of

\footnotetext{
${ }_{11}$ A figure with changes in the Gini coefficients 1950/60-2009, including Russia and China, can be found in Haller [2015: 195].

${ }_{12}$ In 2016, the unemployment rate was 4\% in the Czech Republic, 5\% in Hungary, and 9.7\% in Slovakia; in Austria it was also low with 6\% (WKO). Unemployment among young people in 2016: AT 11\%, CZ 10\%, SK 22\%, HU 13\% (Eurostat).
} 
25-64 year olds with less than an upper secondary level of education is much lower in Slovakia and the Czech Republic than in Austria and Hungary. Furthermore, in Austria many young people (especially young men) enter an apprenticeship in an enterprise after finishing elementary school and while attending a vocational school at the same time, which is why a large number of Austrians having a lower secondary level of educational attainment (over $40 \%$ ). As for the changes that have occurred since 1990, in all three former state-socialist societies the main increase in education was observed at the upper-secondary level; a significant increase in the share of university graduates was observed also, but only in Austria and Slovakia. In the Czech Republic, the percentage of university graduates was already quite high in 1992 (about 10\%).

The OECD data on labour-market participation show a significant decrease in Slovakia and Hungary during the early 1990s (from around $75 \%$ and $65 \%$ to less than $70 \%$ and below $60 \%$ in Slovakia respectively). Later on, it increased again significantly in Slovakia and from 2010 onwards it rose slightly in all four countries. By 2017, the difference between the four countries had become relatively small (around 67\% in Hungary, 70\% in Slovakia, and 75\% in Austria and the Czech Republic).

As for the development of the occupational class structure, both ISSP and ILO data show some commonalities, but also some differences in structures and changes. Austria has the highest proportion of workers in professional and semiprofessional positions at about one-third of the workforce; it is followed in this by the Czech Republic and Slovakia, while Hungary has the smallest share of such workers (less than one-fourth). The percentage of workers, particularly in semiskilled and unskilled jobs, is significantly higher in all post-communist countries (around one-fourth and one-third of the workforce, compared to one-eighth in Austria), despite the fact that their proportion was declining. In these countries, nearly half of all employed people belong to the manual working class (including skilled workers); in Austria it is only one-third. A uniform trend in all four countries was the expansion of routine non-manual jobs; in Austria today such jobs are held by about one-third of the workforce, and in the three neighbouring countries the figure is about one-fourth. These persistent differences may be a consequence of differing levels of development; but they also seem to be related to the specific state-socialist pattern of industrialisation and development. Strong investment from Western (particularly German) industrial firms in manufacturing plants in these post-communist countries may have contributed to the perpetuation of past structures.

\section{Interim conclusions}

We can summarise the findings in this section with three conclusions. First, all three of Austria's East-European neighbouring countries have been rather successful in their transition from a state-socialist to a market society [see also UNDP 2015]. 
The success of the transition becomes evident when we compare Hungary, the Czech Republic, and Slovakia to South-East European countries such as Romania or Bulgaria or, even more, East-European countries such as Ukraine or Belarus. Two factors may have been responsible for this success: One was the positive institutional legacy, in the form of education systems, public administration, and so forth, that these countries inherited from the Austro-Hungarian Empire. Fenger [2007] found that the welfare-state regimes of the Central European countries were developed in a direction that brought them closer to the central European (German) model. The other possible factor is the relatively 'soft' transition from socialism to a market society. What form the transition should take was a hot scientific and political issue in the early 1990s: on one side there was a group (mostly liberal US economists) who favoured a 'big bang' approach through the radical and sharp destruction of the socialist command system in favour of a market system, and on the other hand there was a group calling for a 'soft' transition [von Beyme 1994: 207ff.; Ivanova 2007]. The transition process in Czechoslovakia and Hungary leaned more towards the second type [Laki 2007; Večerník 2009: 14]. Slovakia, in contrast, became the leader in liberal reforms after 2000 (like in the Czech Republic, Slovakia also introduced a flat tax [Stolarik 2016: 238]). Whereas it is difficult to estimate the effects of different modes of transition [Podkaminer 2013], the World Bank [2005] has pointed out that some of the countries that adopted a soft or slow transition process have fared better than those that underwent the fast one. Slovakia has probably experienced the most difficult transition, but it has recovered quite well, if we disregard its high rate of unemployment.

These developments lead to our second conclusion: the differences between Austria and its three former state-socialist neighbours are still quite significant. Three basic indicators can be mentioned in this regard: the persistent differences in levels of income; the fundamental differences in patterns of migration (immigration towards Austria, emigration from the other); and the corresponding changes in the population development-the steady increase in Austria contrasts sharply with the net loss observed in Hungary.

The third general conclusion is that significant differences also persist within the three post-communist countries. In terms of income level and life expectancy, there exists a rank order among the three countries, with the Czech Republic on top and Hungary at the bottom-a ranking that could already be observed in the time of the Austrian Monarchy.

\section{The perception of social stratification and inequality: 1987-2009}

The issue of social inequality and stratification is not only a matter of objective facts and trends, but also one of political rhetoric and subjective perceptions. Similar objective levels of inequality may be perceived and evaluated in quite varied ways by different individuals and social groups, depending on their position in 
the social structure and their personal biographies and future prospects and on the issues and images which prevail in public life and politics [Ossowski 1963; Runciman 1967; Parkin 1972; Letwin 1983; Haller, Mach and Zwicky 1995; Riedl and Haller 2014].

We know that there are situations and countries in which high levels of inequality coexist with little critique from the population. While in the relatively equal countries of Austria and the Czech Republic nearly half of the population agrees strongly with the statement 'income differences are too large', in the United States, where the Gini coefficient is around 40, only around $30 \%$ agree [Haller and Eder 2015: 169].

Dissatisfaction with inequality, however, arises only if people feel that distribution processes and structures are obscure and influenced by clientelism and corruption, if specific groups feel treated and remunerated unfairly, or if strong theories and ideologies emerge which induce people to look critically at such facts [Moore 1979]. The revolutions in the former state-socialist societies, including the Soviet Union, broke out not only because they were lagging behind West European societies, but also because Margaret Thatcher-an influential West European political leader-gave strong support in public to the liberalist credo about the superiority of market economies over state socialism [Lane 2011]. People in socialist Central European countries faced neighbouring countries with significantly higher standards of living, the freedom to travel, and other opportunities. The sharp divide between Western and Eastern Europe diminished with the fall of the Iron Curtain. But the integration of CEE countries into the European Union may have strengthened their inclination to compare their situation with that of people in the old EU member states [Heidenreich 2006; Delhey and Kohler 2016].

In this section, we thus investigate the perception of societal stratification and inequality in our four countries since 1989/1990. The data these analyses are based on come from the four surveys on social inequality carried out in the context of the International Social Survey Programme (ISSP) in 1987, 1992, 1999, and 2009. Every year the ISSP fields a specific module in each country as part of a representative population survey; all the surveys are carried out again several years later. In this way, the ISSP offers two powerful research strategies to study societal change: it combines a cross-time and cross-national perspective [Haller, Jowell and Smith 2009]. ${ }^{13}$ Fortunately, Austria and Hungary have been members of the ISSP since its beginnings in 1984/1985. The Czech Republic and Slovakia are also early members of the ISSP and carried out the ISSP modules on inequality.

\footnotetext{
${ }^{13}$ For detailed information on the ISSP, see www.issp.org and Haller, Jowell and Smith [2009] (in particular Smith [2009]). The ISSP data are retrieved by GESIS in Cologne (Germany) and available to the scientific community worldwide; see https://www.gesis.org/ issp/home/.
} 


\section{Subjective perceptions of social stratification and inequality: theoretical considerations}

There are three frequently used approaches that we can identify in the literature on the perception of social structure and social and economic inequalities: the reflection thesis, the deprivation thesis, and the dominant ideology thesis.

The reflection thesis [see Mau 1997; Hadler 2005; Eder et al. 2018] posits that the objective level of inequality determines its subjective perception and evaluation. Thus, people in unequal societies should be more critical of inequality than those in more equal societies. Perceptions thus should be more critical in Hungary (and possibly Slovakia) than in Austria and the Czech Republic, although the Gini coefficients do not vary much between these countries.

The class position or social deprivation thesis asserts that people who are socio-economically well off and belong to the middle and higher social classes are less critical of the existing patterns of inequality than are people in the lower social classes. This was demonstrated to be a fact in Runciman's [1967] pioneering research on Great Britain and has since been confirmed by many other studies [see, e.g., Verwiebe and Wegener 2000; Hadler 2005; Lengyel 2007; Sauer et al. 2016; Eder 2017].

The dominant societal ideology thesis posits that within any given society a certain worldview or societal ideology is dominant [Abercrombie and Turner 1978]. This 'social consciousness' [Ossowski 1963] arises as the result of a continuous competition between different ideologies [Mannheim 1951]. It has been shown that the content and influences of these ideologies vary significantly between societies [Haller et al. 1995]. The United States is a paradigmatic society where the liberal ideology of equal opportunities prevails, while the Scandinavian countries might represent the opposite position, that of a society where there is support for substantive equality of conditions and considerable redistribution [Willi 1966; Münch 2001; Svallfors 2003]. In this regard, we expect that the heritage of state socialism will result in a stronger perception of the importance of equality in the three East European neighbouring countries than in Austria [see also Gijsberts 2002].

\section{The perception and evaluation of income and income inequality}

Figure 2 shows how the perception and evaluation of income inequality has changed in the four countries since the late 1980s. First, we can see that a large proportion of the respondents consider income inequalities to be too high. Adding the responses 'agree strongly' and 'agree' shows that between 85\% and 95\% of the respondents think so in all countries. Yet, when we consider only those who 'agree strongly', we find, in 2009, that significant differences between the countries exist: 77\% in Hungary, 63\% in Slovakia, 51\% in the Czech Republic, and less than half $(46 \%)$ of respondents in Austria agree strongly. In all the former 
Figure 2. Attitudes towards income inequality

Income differences are too large (\% agree strongly)

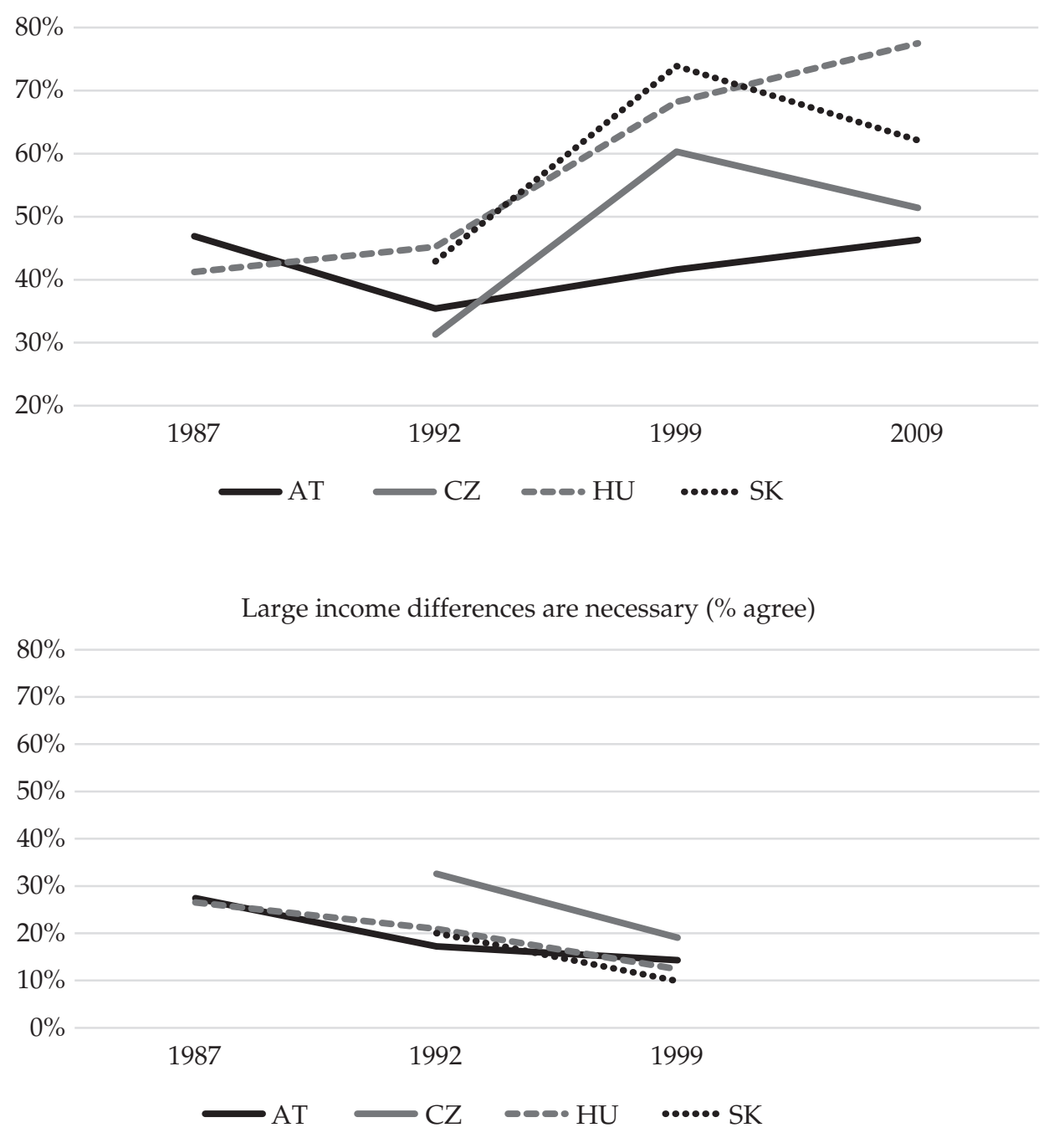

Source: ISSP 1987, 1992, 1999, and 2009. Mean value comparisons based on (a) country differences and (b) country-time groups are all significant. Eta between .115 and .253. 
Figure 3. Perceived income justness

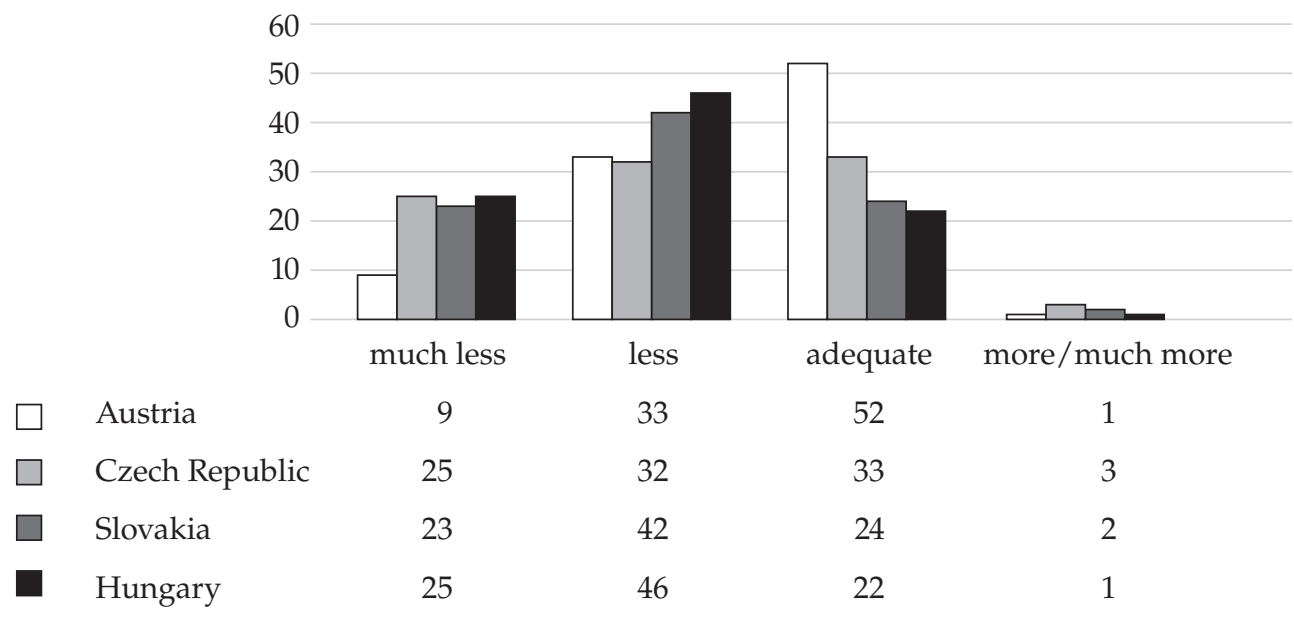

Source: ISSP 2009. The question read: 'Would you say you earn ... than you deserve? The response categories were: much less, less, adequate, more, and much more. Differences are significant, association measures: $\mathrm{phi}=.283^{* *}$ and eta $=.229^{* *}$ when considering all five categories.

state-socialist countries there has also been a marked increase in the proportion of people who consider inequality to be being too high; the proportion who agree fully increased the most in Hungary (from $41 \%$ to $77 \%$ ). These trends parallel the trends in objective levels of inequality as shown in Figure 1.

An inverse change took place on the question about whether 'large differences in income are necessary', which captures a liberal, achievement-oriented evaluation of inequality. In 1987, about one-fourth of Austrians and Hungarians agreed with this statement. By 1999, this proportion dropped to around onetenth. Interestingly, the Czechs are more inclined to support the view that large income differences are necessary. Almost half a century ago Walter Korpi [1978: 323] formulated the thesis that "it is improbable that workers can be "bought off" with an increased standard of living to accept the subordination inherent in the institution of labor'. Today, anti-capitalist revolutionary ideas seem outdated, but high levels of inequality are not be tolerated even in times of economic prosperity. In the past decade, the acceptance of increasing and high inequality has been shrinking in most countries around the world [Dorling 2018].

There are also two facts worth noting on the question of how individual respondents evaluate their own income (Figure 3). First, many more people consider their personal income as being too low, and nearly nobody feels it is too high; this 
is a general empirical finding as pointed out in Runciman's [1967] study. Second, however, there are some significant differences between the countries: In Austria, about half of the respondents think they get an adequate income; but in the three neighbouring former state-socialist countries, this is true of only one-fourth (SK, HU) and one-third (CZ) of the respondents. Interestingly, these evaluations changed little over time, so it is sufficient to present only the data for the last ISSP survey. There are two factors that may explain this significant difference between Austria and its neighbouring countries: One is the fact that wages and salaries are indeed significantly higher in Austria than in the three post-communist countries and people will be aware of this in all four countries. Another explanation could be that the process of wage determination is considered to occur in a fairer and more transparent and way in Austria than in the post-communist countries. Some clues towards an understanding of this difference can be found when we look at the different views on the societal structure in the following section.

\section{The perception of social stratification and self-assessed social position}

The ISSP surveys on social inequality also include pictures of different stratification patterns or models of a society. These range from a picture of a very unequal society, where most people are at the bottom and a few are on top, to a society in which most people are in the upper classes and status groupings (see Figure 4).

Figure 4. The most common views on social stratification in the four countries

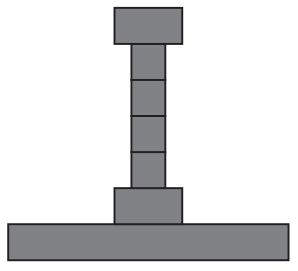

Type A

A small elite, with very few people at the top of society and the great mass of people at the bottom.

Hungary: 1992, 1999, 2009

Slovakia: 1999, 2009

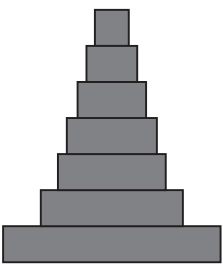

Type B

A pyramidshaped society with a small elite at the top.

Czech Rep.: 1992, 1999, 2009 Slovakia: 1992

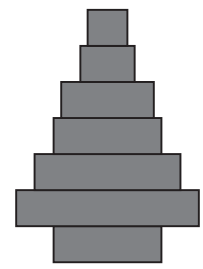

Type C

A pyramidshaped society, except there are only a few people at the bottom.

Austria 2009

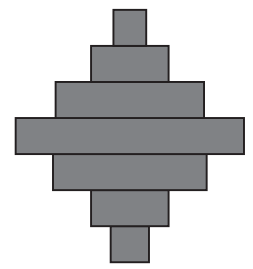

Type D

A society with most people in the middle.

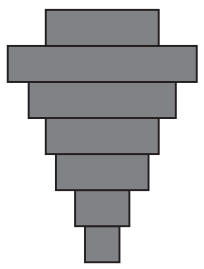

Type E A society with many people near the top.

Source: ISSP 1987, 1992, 1999, and 2009.

Note: Detailed answers and percentages are provided in Table A1. 
Figure 5. Type of society reconstructed from a subjective ranking on a 10-point scale (2009)-first part
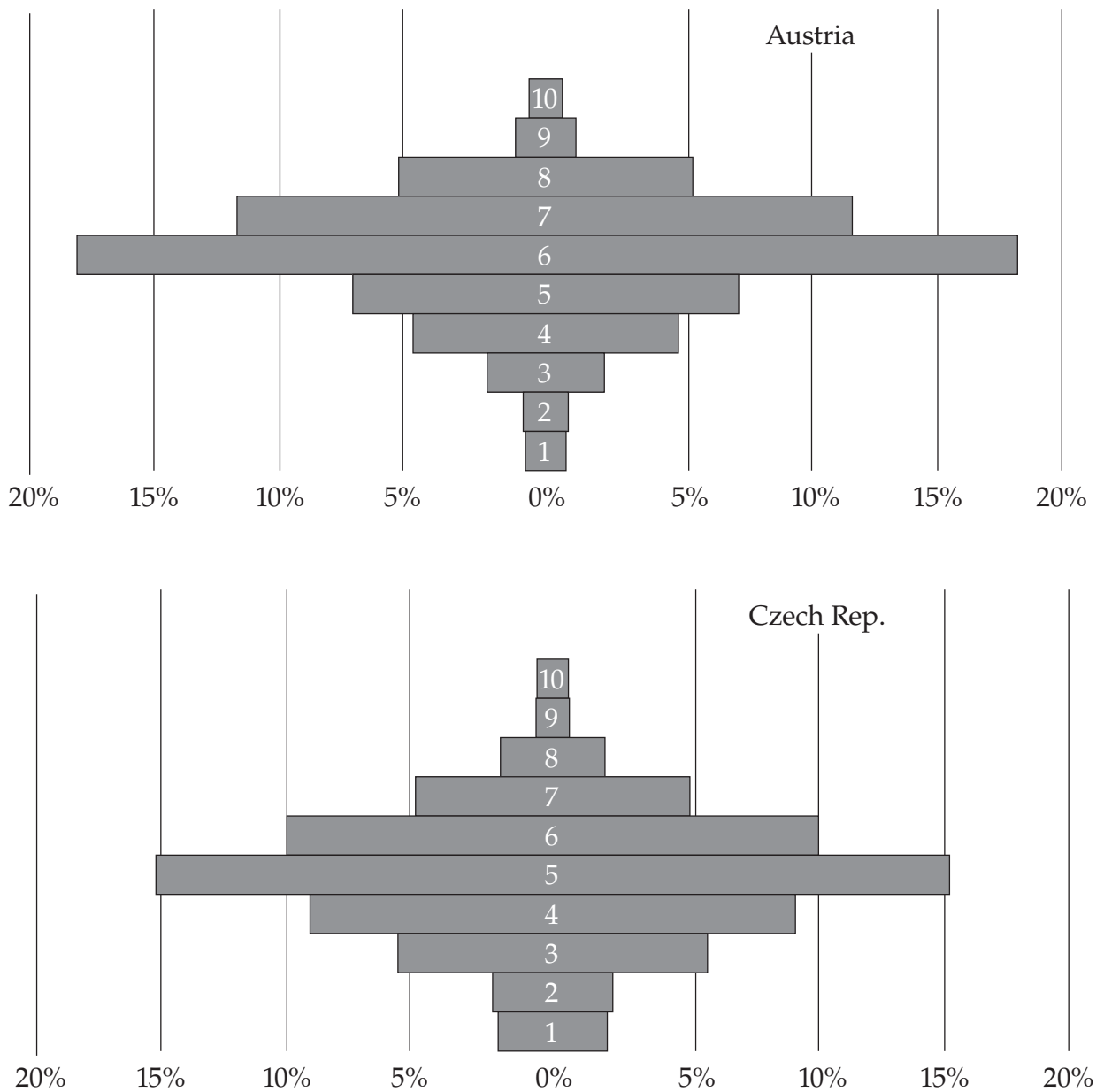

Source: ISSP 2009. 
Figure 5. Type of society reconstructed from a subjective ranking on a 10-point scale (2009)-second part
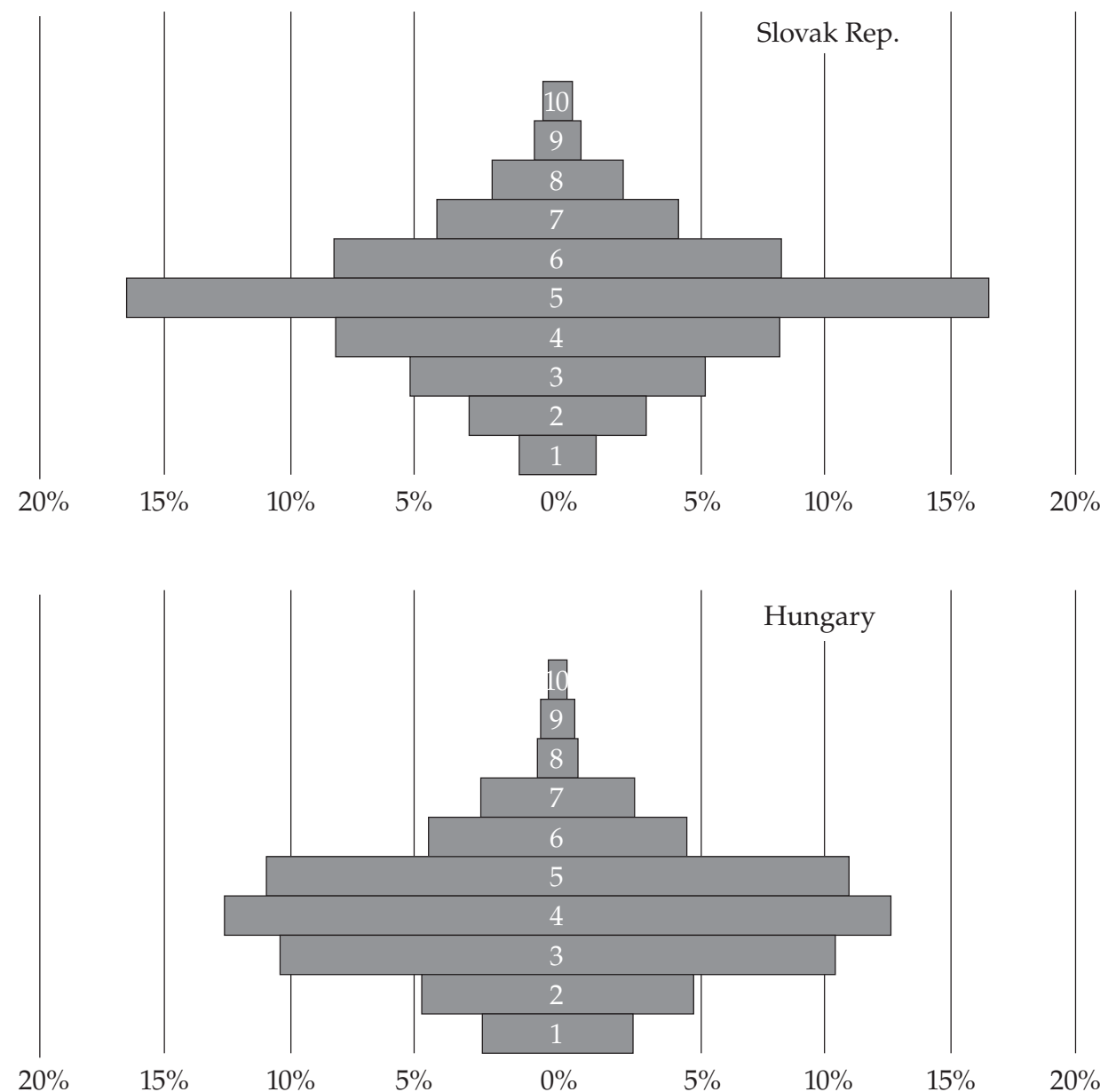

Source: ISSP 2009. 
Respondents are asked which one of these patterns reflects the current stratification in their countries and which stratification pattern they prefer.

On the question of the current stratification in one's country, the dominant view in Austria is that it is a middle-class society (Type $C$ and D); respondents in the Czech Republic see their country as a pyramid (Type B); and in Hungary and twice in Slovakia respondents identified their country as the elite-mass model (Type $\left.\mathrm{A}^{14}\right)$. In the latter two countries, this critical view people take of the social structure is probably also influenced by political developments since 1990 . In both countries authoritarian leaders came to power: in the Slovak Republic Vladimír Mečiar (1990-1998), in Hungary Victor Orbán (1998-2002 and again since 2010). Orbán's regime is regarded with great scepticism by many analysts in Hungary [Lengyel and Rostovany 2011; Szikra 2014; Magyar 2016] and by the European Union. ${ }^{15}$

Table A1 (Appendix) provides more detailed information on respondents' views and preferences regarding the country's social structure. These detailed numbers show that in the three post-socialist societies there is a general, weak tendency to more commonly see the social structure of one's country as polarised between the elites and the masses, while it is less common to regard it as a middle-class society. In Austria, on the other hand, there was a shift in the perception of the social structure from a middle-class to an attenuated pyramid model (D to C). As for the preferred structure, respondents in all four countries favour a society that is dominated by the middle class (D), or even one whose structure is dominated by the upper-middle and upper classes (E). The desired structure corresponds well to the widespread opinion, expressed already by the Greek philosopher Aristotle (384-322 BC), that among the three classes of a society-the rich, the poor, and those in the middle - the last one is the most moderate; therefore, the best society is one with a strong middle class. Another noteworthy trend can also be seen in the three former state-socialist countries: a high proportion of people preferred Model E in 1992, but by 2009 that percentage had dropped significantly in favour of the middle-class and the pyramidal society. This trend can be interpreted as a return to a more realistic view of the social structure in the new, non-socialist context. There exists a significant difference, however, between the Czech Republic and Slovakia versus Hungary: in the former, the preference for a middle class is somewhat weaker than that for a pyramidal society, which may indicate a stronger commitment to the achievement principle.

These views of the social structure parallel the objective changes in the four countries in the last decades. Table 1 showed that the income levels increased massively in all of them. However, the relative income differences between the

\footnotetext{
${ }^{14}$ This view is even more widespread in the post-Soviet communist countries in East Europe [see Riedl and Haller 2014].

15 On 11 September 2018, the European Parliament voted to initiate Article 7 disciplinary procedures against Hungary for undermining democratic rules.
} 
countries did not change significantly; GNP per capita in Austria was 60\% higher than in Czechoslovakia and about twice the level in Hungary. Overall, incomes in Austria today are between two-and-a-half and three times higher than in the Czech Republic and four to five times higher than in Hungary. ${ }^{16}$ This difference is reflected in the subjective self-ranking of individuals in the stratification structure, which we address now.

The ISSP asked respondents to rank themselves on a social status scale going from 1 (lowest) to 10 (highest social position). In Figure 5, this scale is transposed to a vertical axis in order to match the graphics displayed on the cards during the interviews and shown in the previous figure. In Austria, the largest proportion of people class themselves in the middle category; this proportion increased considerably between 2003 and 2016 [Hadler and Klebel 2019]. In the Czech Republic and Slovakia and in Hungary particularly, many more people class themselves into a lower category. Yet, in terms of mean values the average classification/self-ranking has improved in all countries between 1992 and 2009: in Austria from 5.77 to 6.01, in the Czech Republic from 4.78 to 4.87, in Slovakia from 4.56 to 4.86, and in Hungary from 3.92 to 4.04 (see also the regression results in Table 5).

In sum, we observe an overall improvement but also persistent differences. Here the ongoing European integration may have played an important role. European integration fostered labour mobility and financial transfers between the EU member states and thus contributed to the 'Europeanisation of inequality' [Heidenreich 2006]. This is of particular importance as individuals compare themselves also to those in other countries: if the living conditions in one's own country are estimated to be better than in other countries, satisfaction increases [Delhey and Kohler 2006]. In the four CEE countries, which were united within a single empire for centuries, such comparisons were relevant long before European integration started in the late 1950s. Rising incomes and improving living conditions thus can explain the overall increase, and comparisons with neighbouring countries can explain the persistent differences. The subjective self-ranking in the stratification system is thus related to the differences in incomes and living standards in the four countries.

\footnotetext{
16 See the data on mean income in 78 countries of the world at https://www.laenderdaten. info/durchschnittseinkommen.php. According to a report in the Austrian business magazine Trend, a skilled worker in Austria earns three times as much as in the Czech Republic, and 5.85 times as much as in Hungary (see https://www.trend.at/branchen/karrieren/ riesige-lohnunterschiede-oesterreich-tschechien-ungarn-6213889; retrieved 14 October 2018).
} 


\section{Factors influencing perceived social position and income inequality}

After describing differences in the perception of income inequality and societal structures, we now turn to the factors influencing these perceptions. Four individual characteristics are considered in this regard: gender, age, educational level, and occupational class position. In addition, we also include indicators for country and time of the survey.

The findings (see Table 2 on the unstandardised regression coefficients) show that subjective self-ranking is influenced by all the variables: Women and older people rank themselves lower than men and younger people do. Education level and occupational class position are highly relevant as well: the better the education, the higher the self-ranking. In class terms, the higher service class and the self-employed with employees rank themselves in the highest positions, followed by the lower service class and the self-employed without employees. Workers and farm-related classes are at the lower end. Income inequality is (more often) perceived as being too great by women, whereas the other socio-demographic variables do not have a significant effect. As for occupational class and subjective social position, the results show that income differences are not seen as too large by those who rank themselves in higher positions and work in higher occupational classes.

The effects of country and time and of different trajectories within countries (interaction terms) are displayed in Figures $6 a$ and $6 \mathrm{~b}$, which are based on the results of the regression analysis in Table 2. Here we can see that in Hungary people's self-ranking clearly decreased between 1987 and 1992, but no significant changes have occurred since then. A critical view of inequality, however, clearly grew in all the countries, but only in Hungary did it increase continuously throughout the entire period; in the Czech Republic and Slovakia, it increased during the 1990s, but decreased somewhat afterwards. This may be an indication that the transition problems had been overcome in these two countries and they were turning to a new path of positive development.

Our findings are in line with the premises of these three theories: reflection thesis, subjective social position, and dominant ideology. Respondents certainly differ in their perceptions according to their class and subjective position within the four countries. Differences between countries, however, can be seen as a reflection of the objective differences in inequality, but also as influenced by the ideologies of the socialist past. However, we would need to consider additional countries to detangle these macro-level effects. 
Table 2. Determinants of subjective self-ranking and attitudes towards the extent of income differences (unstandardised regression coefficients)

\begin{tabular}{|c|c|c|}
\hline Independent variables & $\begin{array}{c}\text { Income differences } \\
\text { are too large } \\
\text { (disagree - agree) }\end{array}$ & $\begin{array}{l}\text { Self-ranking } \\
\text { (bottom - top) }\end{array}$ \\
\hline & $\mathrm{B}$ & $\mathrm{B}$ \\
\hline Constant & 5.010 & 3.988 \\
\hline Year: 1987 & $-0.386^{* *}$ & $0.348^{* *}$ \\
\hline 1992 & $-0.375^{* *}$ & $-0.145 *$ \\
\hline 1999 & .004 & $-0.228 * *$ \\
\hline 2009 & Ref & Ref \\
\hline Country: Austria & $-0.116 * *$ & $1.034 * *$ \\
\hline Czech Republic & $-0.253 * *$ & $0.106^{*}$ \\
\hline Hungary & $-0.109 * *$ & $-0.363 * *$ \\
\hline Slovak Republic & Ref & Ref \\
\hline Interactions Country * Year & See Fig. 6a & See Fig. 6b \\
\hline Female & $0.053 * *$ & $-0.146^{* *}$ \\
\hline Age (years) & 0.001 & $-0.010 * *$ \\
\hline Education (years) & -0.005 & $0.900 * *$ \\
\hline \multicolumn{3}{|l|}{ Occupational class position (EGP) } \\
\hline I: Higher service class & $-0.285^{* *}$ & $0.804^{* *}$ \\
\hline II: Lower service class & $-0.188 * *$ & $0.719 * *$ \\
\hline IIIa: Routine non-manual & -0.152 & $0.425 * *$ \\
\hline IIIb: Lower sales/services & -0.175 * & $0.306^{* *}$ \\
\hline IVa: Self-employed with employees & -0.166 & $1.174 * *$ \\
\hline IVb: Self-employed, no employees & $-0.208 *$ & $0.714 * *$ \\
\hline V: Manual supervisors & -0.093 & $0.386^{* *}$ \\
\hline VI: Skilled workers & -0.106 & 0.126 \\
\hline VIIa: Unskilled workers & $-0.157 * *$ & 0.073 \\
\hline VIIb: Farm labour & $-0.128^{*}$ & -0.036 \\
\hline IVc: Self-employed farmer & Ref & REF \\
\hline Subj. self-ranking (low-high) & $-0.064^{* *}$ & Not included \\
\hline
\end{tabular}

Source: ISSP 1987, 1992, 1999, and 2009.

Note: Statistical significance: ${ }^{*} \leq .05,{ }^{* *} \leq .01$. 
Figure 6a. Attitudes toward inequality (interaction effects, see Table 2)

Income differences are too large

5.20

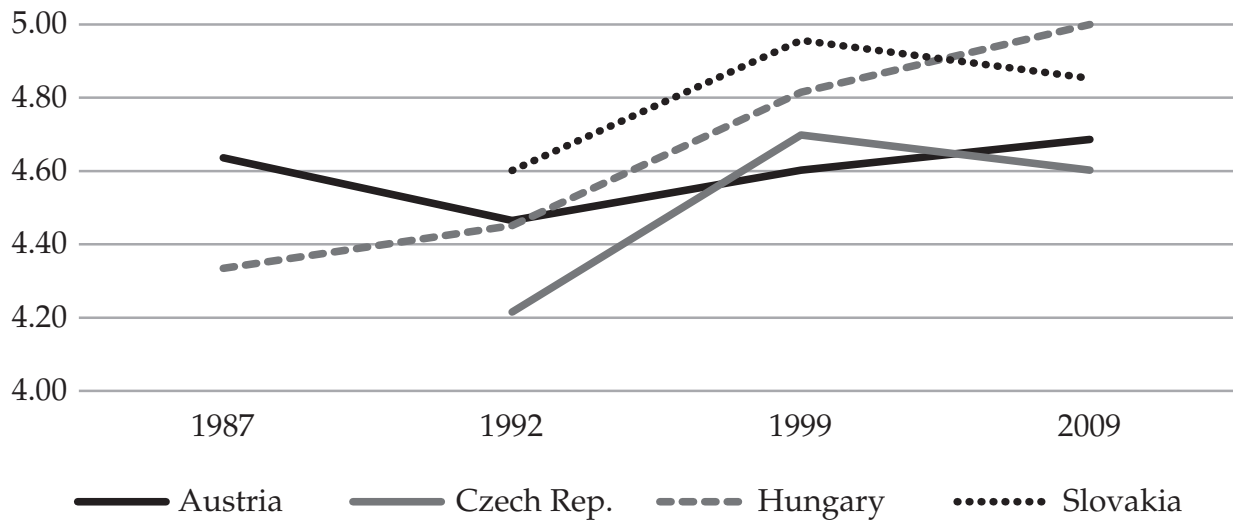

Figure $6 \mathrm{~b}$. Self-ranking over time and across countries (interaction effects, see Table 2)

$$
\text { Top - Bottom }
$$

6.00

5.50

5.00

4.50

3.50

3.00

1987

1992

1999

2009

Austria

Czech Rep.

-- Hungary

Slovakia 


\section{Conclusion}

This article started out with three general hypotheses about social-structural development in Austria and its three former state-socialist neighbouring countries: First, we assumed that the socialist transformation of these countries has had a significant impact on their patterns of development, including a reduction of economic inequality. However, we also considered that the democratic, consensusoriented economic-political system of Austria may have been able to curb the rise of inequality as well. Second, we argued that a longer historical-sociological perspective is needed: structural differences between these countries, which extend back to the 19th century and are connected with the division of labour between the different parts of the Austro-Hungarian Empire, may still have an effect today. In this perspective, Hungary should be characterised by more pervasive inequality than the other three countries. Third, we argued that the perceptions and evaluations of inequality are linked to the historical developments and differences in the structures of these societies.

Our descriptive analyses of the historical developments and subjective perceptions confirmed these general three hypotheses. First, all four countries belong to relatively equal societies from a European and global perspective. The transition of the former Central European state-socialist countries to capitalistmarket and politically democratic societies in the early 1990s provided them with a new and more dynamic path of development. A UN report stated that by 2008 most post-socialist countries had reached or surpassed their pre-transition levels of income per capita and mortality had significantly decreased. However, it also pointed to new problems such as the deteriorating situation of specific social groups [Brainerd 2010]. Hungary and Slovakia, for example, also have larger shares of Roma people, who are discriminated against in many ways. ${ }^{17}$

We have also shown that the subjective perceptions of inequality structures vary significantly between these countries. While Austrians consider their society a middle-class society, Czechs see theirs as a hierarchically structured pyramid, and Hungarians theirs as one with a few people at the top and many at the bottom. The Slovak perception lies between the latter two. It seems that these perceptions are also based on people's comparisons of their own position with the situation of people in more developed West European countries. A German study asked people which inequalities they consider just or unjust-ones that relate to the characteristics of the individual, of enterprises, or of society as a whole-and found that the latter (in this case, the income differences between West and East Germany) were most often seen as unjust [Sauer et al. 2016].

Finally, it also evident, that changes in the social structure and their perception must be seen in connection with ongoing processes and problems in the

17 See EU Commission, Integration of Romas (Press Release), 2 April 2014 (http://europa. eu/rapid/press-release_MEMO-14-249_de.htm, retrieved 22 October 2018). 
political sphere. When people feel that their interests are not represented well by interest organisations and responsible political parties and leaders, their trust in the economic and political system declines and profound feelings of uneasiness and depression will grow. These developments are reflected, for example, in the level of union organisation among employed people: it declined significantly in the Czech Republic and Hungary (from around 15\% in 2002 to around 5\% in 2014), while it remained comparatively high in Austria (29\% and 25\%; Dieke and Lesch [2017]). Furthermore, the instability of the system of political parties has been an endemic problem in all post-communist countries in Eastern Europe and turnout at national elections in the 2010-2016 period was significantly lower in the post-communist CEE countries than in Austria [Eder, Volk and Haller 2017].

Alongside these political changes, corruption remains another urgent topic in CEE countries. It is generally seen as a serious problem by the populations in all the CEE countries [Lengyel 2007]. Austria ranks 16th on the International Corruption Perception Index among 180 countries, whereas the other countries rank far worse: the Czech Republic ranks 42nd, Slovakia 54th,' and Hungary 66th. ${ }^{18}$ At the time the writing of this manuscript was reaching completion (the end of June 2019), over 100000 people were demonstrating in Prague against the Czech Premier, who was accused of having misused EU agricultural subsidies for his own firms (see footnote 8). The rise of populist leaders to power has thus only aggravated the problems in the political system [on Hungary, see Magyar 2016].

Finally, the accession of the CEE countries to the European Union in 2004 has certainly assisted them in achieving economic growth and establishing democratic institutions. However, the hasty process of integration has also led to problematic consequences, such as businesses in many sectors being taken over by foreign capital and the massive emigration of younger and economically active people to the West. These developments have been accompanied by the increasing prevalence of authoritarian attitudes in Slovakia and Hungary, more so than in the Czech Republic [Večerník 1995], and may have fostered feelings of having been exploited, powerlessness, and, especially among less privileged groups, the perception of having been left behind [Uhlova 2018].

\footnotetext{
${ }^{18}$ See https://www.transparency.org/news/feature/corruption_perceptions_index_2017 \#table (16 October 2018).
} 
MAX HALLER was a professor of sociology at the University of Graz (Austria) in 19852015. He was president of the Austrian Sociological Association and is a member of the Austrian Academy of Science. He was co-founder and vice president of the European Sociological Association and co-founder of the International Social Survey Programme (ISSP). He has been a visiting professor at universities in Germany, Hungary, the Czech Republic, Italy, the United States, and Tanzania and he has published and edited 40 books and around 250 papers in international sociological journals including AJS, ASR, Revue française de sociologie, and International Sociology.

MARKUS HADLER is a professor of sociology at the University of Graz, Austria, and honorary professor at the Department of Sociology at Macquarie University, Australia. Hadler is also Austrian representative to the International Social Survey Programme (ISSP). His research interests lie in the areas of social inequality, political sociology, and environmental sociology.

\section{References}

Abercrombie, N. and B. S. Turner. 1978. 'The Dominant Ideology Thesis.' British Journal of Sociology 29 (2): 149-170, https://doi.org/10.2307/589886.

Altzinger, W., N. Lamei, B. Rumplmaier and A. Schneebaum. 2013. 'Intergenerationale soziale Mobilität in Österreich.' Statistische Nachrichten 68 (1): 48-62.

Atoyan, R., L. Christiansen, A. Dizioli, C. Ebeke, N. Ilahi, A. Ilyina, G. Mehrez, H. Qu, F. Raei, A. Rhee and D. Zakharova. 2016. Emigration and Its Economic Impact in Eastern Europe. IMF Discussion Note. Washington, DC: International Monetary Fund, https://doi.org/10.5089/9781475576368.006.

Bahna, M. 2016. 'Ten Years after the Post-Accession Migration Wave from EU 8 to the UK: What Can We Learn from the Largest Intra-EU Migration Experiment?' Österreichische Zeitschrift für Soziologie 41 (4): 373-389, https://doi.org/10.1007/s11614-016-0244-4.

Baravalle, A. 2009. Systemwechsel und Transformationsprozess in Polen und Tschechien. Diploma thesis, University of Vienna, Department of Political Science.

Breinerd, E. 2010. Human Development in Eastern Europe and the CIS since 1990. New York: United Nations Human Development Programme. Retrieved 23 November 2018 (http://hdr.undp.org./en/content/human-development-eastern-europe-andcis-1990).

Connor, W. D. 1979. Socialism, Politics, and Equality. Hierarchy and Change in Eastern Europe and the USSR. New York: Columbia UP, https://doi.org/10.7312/conn92866.

Delhey, J. and U. Kohler. 2006. 'Europäisierung sozialer Ungleichheit.' Pp. 339-358 in Die Europäisierung sozialer Ungleichheit. Zur transnationalen Klassen- und Sozialstrukturanalyse, edited by M. Heidenreich. Frankfurt and New York: Campus.

Dieke, S. and H. Lesch. 2017. Gewerkschaftliche Mitgliederstrukturen im europäischen Vergleich. Ergebnisse des European Social Survey (=IW-Trends 3/2017). Cologne: Institut der Deutschen Wirtschaft.

Djilas, M. 1959. Die neue Klasse. Eine Analyse des kommunistischen Systems. Munich: Kindler. 
Dorling, D. 2018. Do We Need Economic Inequality? Cambridge and Medford, MA: Polity Press.

Eddie, S. M. 1989. 'The Social Distribution of Landed Wealth in Hungary, ca. 1910.' Research in Economic History Suppl. 5: 219-249.

Eder, A. 2017. Veränderung der Wahrnehmung sozialer Ungleichheit in den 1990er und 2000er Jahren: Ländervergleichende Analysen in Zeiten steigender Ungleichheit, zunehmender Globalisierung und osteuropäischer Transformation. Sociological Dissertation, University of Graz, https:// doi.org/10.1080/00207659.2017.1335524.

Eder, A., H. Volk and M. Haller. 2017. 'Patterns of Social Ties, Trust and Participation after the Fall of the Iron Curtain: New Findings from Central and Southeast European Countries.' International Journal of Sociology 47 (3): 147-161.

Eder, A., M. Hadler and M. Schweighart. 2018. 'Über das scheinbare Paradoxon der Zugehörigkeit zur gesellschaftlichen Mitte. Eine quantitative und qualitative Analyse der subjektiven sozialen Position der ÖsterreicherInnen 1993-2016.' SWS-Rundschau 58 (2): 203-224.

Fenger, M. 2007. 'Welfare Regimes in Central and Eastern Europe: Incorporating Postcommunist Countries in a Welfare Regime Typology.' Contemporary Issues and Ideas in Social Sciences 3 (2): 1-30.

Geissler, R. 1983. 'Bildungschancen und Statusvererbung in der DDR.' Kölner Zeitschrift für Soziologie und Sozialpsychologie 38 (4): 913-940.

Gijsberts, M. 2002. 'The Legitimation of Income Inequality in State-Socialist and Market Societies.' Acta Sociologica 45 (4): 269-285, https://doi.org/10.1177/000169930204500402.

Good, D. F. 1984. The Economic Rise of the Habsburg Empire, 1750-1914. Berkeley, CA: University of California Press.

Hadler, M. 2005. 'Why Do People Accept Different Income Ratios? A Multi-level Comparison of Thirty Countries.' Acta Sociologica 48 (2): 131-154, https://doi.org/10.1177/0001699305053768.

Hadler, M. and T. Klebel. 2019. 'Einkommensungleichheit, Lebensstandard und soziale Position im Zeitvergleich.' Pp. 115-130 in Sozialstruktur und Wertewandel in Österreich, edited by J. Bacher et al. Wiesbaden: Springer VS, https://doi.org/10.1007/978-3-658-21081-6_6.

Haller, M. 1982. Klassenbildung und soziale Schichtung in Österreich. Frankfurt and New York: Campus.

Haller, M. 1990. 'The Challenge for Comparative Sociology in the Transformation of Europe.' International Sociology 5 (2): 183-204.

Haller, M. 1996. Identität und Nationalstolz der Österreicher. Gesellschaftliche Ursachen und Funktionen - Herausbildung und Transformation seit 1945 - Internationaler Vergleich. Vienna, Cologne and Weimar: Böhlau, https://doi.org/10.7767/9783205123521.

Haller, M. 2008. European Integration as an Elite Process. The Failure of a Dream? New York and London: Routledge, https://doi.org/10.4324/9780203927304.

Haller, M. 2011. 'Values and Interests in Processes of Macro-Regional Integration.' Pp. 25-44 in Global Trends and Regional Development, edited by N. Genov. New York, London: Routledge.

Haller, M. and B. Mach. 1984. 'Structural Changes and Mobility in Capitalist and Socialist Society. A Comparison of Men in Austria and Poland.' Pp. 43-103 in International Comparative Research: Social Structure and Public Institutions in Eastern and Western Europe, edited by Niessen et al. Oxford: Pergamon Press, https://doi.org/10.1016/B978-0-08-031334-4.50010-2.

Haller, M., T. Kolosi and P. Robert. 1990. 'Social Mobility in Austria, Czechoslovakia, and Hungary. An Investigation of the Effects of Industrialization, Socialist Revolution, and 
National Uniqueness.' Pp. 153-197 in Class Structure in Europe, edited by M. Haller. New York and London: Armonk, https://doi.org/10.4324/9781315489698-6.

Haller, M., B. Mach and H. Zwicky. 1995. 'Egalitarismus und Antiegalitarismus zwischen gesellschaftlichen Interessen und kulturellen Leitbildern. Ergebnisse eines internationalen Vergleichs.' Pp. 221-264 in Soziale Ungleichheit und soziale Gerechtigkeit, edited by H.-P. Müller and B. Wegener. Opladen: Leske + Budrich, https://doi.org/10.1007/978-3-663-11419-2_9.

Haller, M. and R. Ressler. 2005. 'Schlechte Arbeitsmarktchancen von Jugendlichen verringern die Geburtenrate.' Wirtschaft und Gesellschaft 31 (4): 583-590.

Haller, M., R. Jowell and T. W. Smith. (eds) 2009. The International Social Survey Programme, 1984-2009. Charting the Globe. London and New York: Routledge, https://doi.org/10.4324/9780203880050.

Haller, M., M. Hadler and G. Kaup. 2013. 'Leisure Time in Modern Societies: A New Source of Boredom and Stress?' Social Indicators Research 111 (2): 403-434, https://doi.org/10.1007/s11205-012-0023-y.

Haller, M. and A. Eder. 2015. Ethnic Stratification and Socioeconomic Inequality around the World. The End of Exclusion and Exploitation? London and New York: Routledge.

Haller, M., A. Eder and B. Müller. 2015. ‘Drei Wege zur Zähmung des Kapitalismus. Die Wahrnehmung und Bewertung sozialer Ungleichheit in Deutschland, Österreich und der Schweiz.' Österreichische Zeitschrift für Soziologie 40: 1-31, https://doi.org/10.1007/s11614-015-0153-y.

Haller, M. and R. Verwiebe. 2016. 'Central Europe as a Space of Transnational Migration.' Österreichische Zeitschrift für Soziologie 41 (4): 361-371, https://doi.org/10.1007/s11614-016-0250-6.

Hegedüs, A. 1977. The Structure of Socialist Society. London: Constable.

Heidenreich, M. 2006. Die Europäisierung sozialer Ungleichheit. Zur transnationalen Klassen- und Sozialstrukturanalyse. Frankfurt and New York: Campus.

Ivanova, M. 2007. 'Inequality and Government Policies in Central and Eastern Europe.' East European Quarterly 41 (2): 167-204.

Kaser, M. C. and E. A. Radice. 1985. The Economic History of Eastern Europe 1919-1975. Oxford: Clarendon Press.

Konrad, G. and I. Szelenyi. 1979. The Intellectuals on the Road to Class Power. New York: Harcourt, Brace Jovanovich.

Kopsidis, M. 2006. Agricultural Development and Impeded Growth: The Case of Hungary 1870-1970. IEHC Helsinki: Session.

Korpi, W. 1978. The Working Class in Welfare Capitalism. Work, Unions and Politics in Sweden. London, UK, and Boston, MA: Routledge \& Kegan Paul.

Laki, M. 2007. 'Attitudes and Actions of the Members of the Hungarian Business Elites towards Foreign Owned Companies.' Pp. 199-210 in Restructuring of the Economic Elites after State Socialism, edited by D. Lane, G. Lengyel and J. Tholen. Stuttgart: ibidem Verlag.

Lane, D. 1971. The End of Inequality? Stratification under State Socialism. Harmondsworth: Penguin.

Lane, D. 2011. Elites and Classes in the Transformation of State Socialism. New Brunswick, NJ, and London: Transaction Publishers.

Lehmbruch, G. (ed.) 1982. Patterns of Corporatist Policy-Making. London: Sage.

Leitner, A. and A. Wroblewski. 2019. 'Soziale Mobilität von Frauen und Männern. Einflussfaktoren und Grenzen der Aufstiegschancen.' Pp. 159-173 in Sozialstruktur und Wertewandel in Österreich, edited by J. Bacher et al. Wiesbaden: Springer VS, https://doi.org/10.1007/978-3-658-21081-6_8. 
Lengyel, G. 2007. 'Hungarian Economic Policy Makers and Businessmen in the 1990s: Similarities and Differences.' Pp. 97-114 in Restructuring of the Economic Elites after State Socialism, edited by D. Lane, G. Lengyel and J. Tholen. Stuttgart: ibidem Verlag.

Lengyel, G. and Z. Rsotovány. (eds) 2011. The Small Transformation. Society, Economy and Politics and the New European Architecture. Budapest: Akadémiai Kiadó.

Lenski, G. 1978. 'Marxist Experiments in Destratification: An Appraisal.' Social Forces 57 (2): 364-383, https:// doi.org/10.2307/2577674.

Letwin, W. (ed.) 1983. Against Equality. Readings on Economic and Social Policy. London and Basingstoke: Macmillan, https://doi.org/10.1007/978-1-349-17175-0.

Lupri, E. 1983. The Changing Position of Women in Family and Society. A Cross-national Comparison. Leiden: Brill.

Magyar, B. 2016. Post-Communist Mafia State. The Case of Hungary. Budapest: CEU Press.

Mannheim, K. 1951. Ideology and Utopia. An Introduction to the Sociology of Knowledge. New York: Harcourt, Brace.

Matějů, P. and N. Lim. 1995. 'Who Has Gotten Ahead after the Fall of Communism?' Czech Sociological Review 3 (2): 117-136.

Mathis, F. 2007. Reiches Österreich. Fleiß oder Glück—warum geht es uns so gut? Innsbruck, Vienna and Bozen: Studienverlag.

Mau, S. 1997. 'Ideologischer Konsens und Dissens im Wohlfahrtsstaat. Zur Binnenvariation von Einstellungen zur sozialen Ungleichheit in Schweden, Großbritannien und der Bundesrepublik Deutschland.' Soziale Welt 48 (1): 17-37.

Mejstrik, M. (ed.) 1997. The Privatization Process in East-Central Europe. Evolutionary Process of Czech Privatizations. Norwell, MA: Kluwer Academic Publications.

Milanovic, B. 2005. Worlds Apart. Measuring International and Global Inequality. Princeton, NJ: Princeton University Press.

Ministry of Education and Culture. 2008. Education in Hungary. Past, Present, FutureAn Overview. Budapest: Department for EU Relations, Ministry of Education.

Möller, J. P. H. 1974. Wandel der Berufsstruktur in Österreich zwischen 1869 und 1961. Vienna: Verband der Wissenschaftlichen Gesellschaften Österreichs.

Moore, B. 1979. Injustice. The Social Bases of Obedience and Revolt. London: MacMillan.

Münch, R. 2001. The Ethics of Modernity. Formation and Transformation in Britain, France, Germany and the USA. Langham: Rowman \& Littlefield.

Nee, V. 1989. 'A Theory of Market Transition: From Redistribution to Markets in State Socialism.' American Sociological Review 54 (5): 663-681, https://doi.org/10.2307/2117747.

Nolan B., W. Salverda, D. Checchi, I. Marx, A. McKnight, I. G. Tóth and H. G. van de Werfhorst. (eds) 2014. Changing Inequalities and Societal Impacts in Rich Countries Experiences. Oxford: Oxford University Press, https://doi.org/10.1093/acprof:oso/9780199687428.001.0001.

OECD. 2010. 'A Family Affair: Intergenerational Social Mobility across OECD Countries.' Pp. 183-200 in Economic Policy Reforms. Going for Growth. Paris: OECD.

Offe, C. 1994. Der Tunnel am Ende des Lichts. Erkundungen der politischen Transformation im Nahen Osten. Frankfurt and New York: Campus.

Ossowski, S. 1963. Class Structure in the Social Consciousness. New York: Free Press.

Parkin, F. 1972. Class Inequality and Political Order. Social Stratification in Capitalist and Communist Societies. London: Paladin.

Pelinka, A. 1981. Modellfall Österreich? Möglichkeiten und Grenzen der Sozialpartnerschaft? Vienna: Braumüller.

Piketty, T. 2014. Capital in the Twenty-First Century. Cambridge, MA: Belknap Press. 
Podkaminer, L. 2013. Development Patterns of Central and East European Countries (in the Course of EU Accession), Research Report 288. Vienna: Vienna Institute for International Economic Studies.

Prisching, M. 1996. Die Sozialpartnerschaft. Modell der Vergangenheit oder Modell für Europa? Vienna: Manz.

Riedl, F. and M. Haller. 2014. 'From Socialist Equality to Capitalist Stratification: How People See It.' Corvinus Journal of Sociology and Social Policy 5: 3-34, https://doi.org/10.14267/cjssp.2014.01.01.

Runciman, W. G. 1967. Relative Deprivation and Social Justice. London: Routledge and Kegan Paul.

Sauer, C., P. Valet and S. Liebig. 2016. 'Welche Lohngleichheiten sind gerecht?' Kölner Zeitschrift für Soziologie und Sozialpsychologie 68: 619-645, https://doi.org/10.1007/s11577-016-0385-2.

Smith, T. W. 2009. 'The ISSP: History, Organization and Members, Working Principles and Outcomes: An Historical-Sociological Account'. Pp. 24-49 in The International Social Survey Programme 1984-2009, edited by M. Haller, R. Jowell and T. Smith. London and New York: Routledge.

Solga, H. 1995. Auf dem Weg in die klassenlose Gesellschaft? Klassenlagen und Mobilität zwischen Generationen in der DDR. Berlin: Akademie Verlag, https://doi.org/10.1515/9783050071534.

Solt, F. 2016. 'The Standardized World Income Inequality Data Base.' Social Science Quarterly 97 (5): 1267-1281. Retrieved 12 July 2019 (https://doi.org/10.1111/ssqu.12295), https://doi.org/10.1111/ssqu.12295.

Stiglitz, J. E. 2013. The Price of Inequality. New York: Norton.

Stolarik, M. M. (ed.) 2016. The Czech and Slovak Republics. Twenty Years of Independence 1993-1013. Budapest and New York: Central European University Press.

Svallfors, S. 2003. 'Welfare Regimes and Welfare Opinions: A Comparison of Eight Western Countries.' Pp. 171-196 in European Welfare Production, edited by J. Vogel. Netherlands: Springer, https://doi.org/10.1007/978-94-007-0977-5_7.

Szelenyi, S. 1998. Equality by Design. The Grand Experiment in Destratification in Socialist Hungary. Stanford, CA: Stanford UP.

Szikra, D. 2014. 'Democracy and Welfare in Hard Times. The Social Policy of the Orbán Government in Hungary between 2010 and 2014.' Journal of European Social Policy 24 (5): 486-500, https://doi.org/10.1177/0958928714545446.

Therborn, G. 1995. European Modernity and Beyond. The Trajectory of European Societies 1945-2000. Thousand Oaks, CA: Sage, https://doi.org/10.4135/9781446222317.

Toth, I. G. 2014. 'Revisiting Grand Narratives of Growing Income Inequality: Lessons from 30 Country Studies.' Pp. 11-47 in Changing Inequalities and Societal Impacts in Rich Countries: Thirty Countries Experiences, edited by B. Nolan et al. Oxford: Oxford UP, https://doi.org/10.1093/acprof:oso/9780199687428.003.0002.

Toth, I. G. 2016. 'Keeping Inequality on a Short Leash: Whose Task?' The World Financial Review, December 5.

Uhlova, S. 2018. 'If the Czech Economy Is Thriving, Why Are We so Poor?' The Guardian, 19 September. Retrieved 16 October 2018 (https://www.theguardian.com/ commentisfree/2018/sep/19/czech-republic-transition-state-socialism-capitalism).

UNDP. 2015. Human Development Report 2015. New York: United Nations Human Development Programme.

Večerník, J. 1995. 'Economic and Political Man. Hardship and Attitudes in the Czech Republic and Central Europe.' Czech Sociological Review 3 (2): 157-177.

Večerník, J. 2009. Czech Society in the 2000s: A Report on Socio-economic Policies and Structures. Prague: Academia. 
Večerník, J. and P. Matěju․ (eds) 1999. Ten Years of Rebuilding Capitalism: Czech Society after 1989. Prague: Academia.

Verwiebe, R. and B. Wegener. 2000. 'Social Inequality and the Perceived Income Justice Gap.' Social Justice Research 13 (2): 123-149, https://doi.org/10.1023/ A:1007545823040. von Beyme, K. 1975. Ökonomie und Politik im Sozialismus. Ein Vergleich der Entwicklung in den sozialistischen Ländern. Munich: Piper.

von Beyme, K. 1994. Systemwechsel in Osteuropa. Frankfurt am Main: Suhrkamp.

Voslensky, M. 1984. Nomenklatura: The Soviet Ruling Class. Garden City, NY: Doubleday. Willi, V. 1966. Grundlagen einer empirischen Soziologie der Werte und Wertsysteme. Zürich: Orell Füssli.

World Bank. 2005. Economic Growth in the 1990s: Learning from a Decade of Reform. Washington, DC: World Bank. 


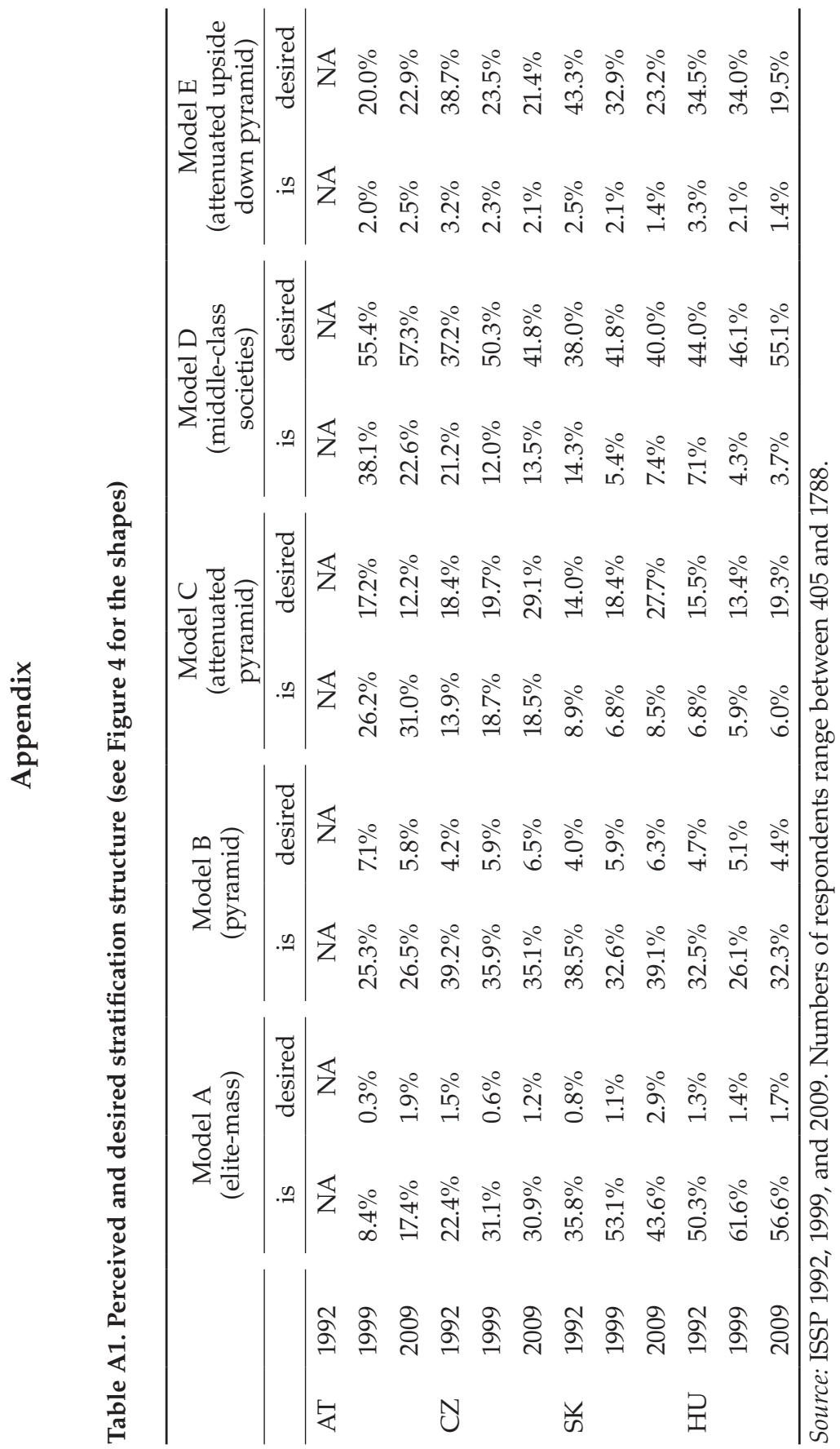

